\title{
A Review of Institutional Experience of Hepatic Resection for Hepatoblastoma
}

\author{
Authors \\ Dr Sunil S Menon ${ }^{1 *}$, Dr Vivek P Sarma ${ }^{2}$, Dr R Hema ${ }^{3}$ \\ ${ }^{1}$ Additional Professor, ${ }^{2}$ Associate Professor, ${ }^{3}$ Professor (Retired) \\ SAT Hospital, Government Medical College, Thiruvananthapuram, Kerala, India \\ *Corresponding Author \\ Dr Sunil S Menon
}

12 Vasanth Vihar Gardens Kumarapuram, Thiruvananthapuram, Kerala, India, Pin 695011

Email:drsunils@gmail.com, Phone 9446127448, Phone 04712528390

\section{Aim of the Study}

To analyze the pattern of clinical presentation and diagnostic investigations in Hepatoblastoma, and to discuss the results of Hepatic resection with neoadjuvant and/or adjuvant chemotherapy

\section{Method of Study}

Retrospective analysis of all the hospital data of 10 children who underwent Hepatic resection for Hepatoblastoma during the period of May 2004 to May 2006 was studied, as a part of a long term study of all cases of Hepatic resection done during the period of $2004-2018$ at a single institution, which has been divided into 3 phases : 2004-06, 2007-10 and 2011-18. The results during the period of 2004-2006 is being presented here as a pilot study.

Primary Hepatic resection for hepatoblastoma and surgeries done after neo-adjuvant chemotherapy are included in the analysis.

\section{Diagnostic Investigations Used}

1. Ultrasound scan of abdomen

2. Serum Alfa- feto protein

3. Chest $X$ ray

4. CT Scan of abdomen

5. FNAC / Tru-cut biopsy of Liver

Patients with un-favorable features that preclude primary resection were selected for upfront chemotherapy. Results of pre operative chemotherapy were assessed. Patients were reevaluated for resectablity after completing chemotherapy. Intra operative findings, extent of surgery and intra operative course was studied. Post operative course and complications were noted. All patients received post operative chemotherapy. Results of post operative chemotherapy were assessed. Patients were followed up clinically and with serial AFP and USS Abdomen. Any evidence of recurrence was sought. 


\section{Results}

Mean age at diagnosis was 2.9 years. Sex incidence was $M: F=6: 4$. No associated anomalies were detected in any of the cases. No significant post natal history/prematurity association was observed. Most commonly, children presented with mass abdomen.

Table 1: Clinical presentation of Hepatoblatoma

\begin{tabular}{|l|c|}
\hline CLINICAL PRESENTATION & $\begin{array}{c}\text { Total number of patients; } \\
\mathrm{n}=10\end{array}$ \\
\hline $\begin{array}{l}\text { Mass detected by parents / } \\
\text { physician }\end{array}$ & 7 \\
\hline Liver lesion detected on USS & 3 \\
\hline Anorexia & 8 \\
\hline Significant loss of weight & 5 \\
\hline Abdominal pain & 8 \\
\hline Fever & 6 \\
\hline
\end{tabular}

Table 2: Pre Operative Serum AFP (NG/ ML)

\begin{tabular}{|c|c|}
\hline 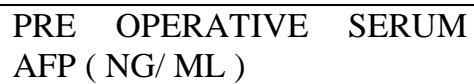 & $\begin{array}{c}\text { Total number of patients; } \\
n=10\end{array}$ \\
\hline $5000-10,000$ & 4 \\
\hline $11,000-20,000$ & 4 \\
\hline 20,000 & 2 \\
\hline
\end{tabular}

The lowest S.AFP was $5020 \mathrm{ng} / \mathrm{ml}$ and the highest S.AFP was $27,400 \mathrm{ng} / \mathrm{ml}$.

\section{Platelet Count}

1. Value $<4$ lakhs $/ \mathrm{mm} 3: 8$

2. Value $>4$ lakhs $/ \mathrm{mm} 3: 2$

\section{Hemoglobin}

1. $<8 \mathrm{~g} / \mathrm{dl}: 1$

2. $8-10 \mathrm{~g} / \mathrm{dl}: 4$

3. $>10 \mathrm{~g} / \mathrm{dl}: 5$

\section{Site of Lesion (USS, CECT)}

The lesion involved the Right lobe in 9 patient and left lobe in 1patient.

Table 3 : Site of the lesion and PRETEXT staging

\begin{tabular}{|l|c|c|}
\hline Segment(s) involved & $\begin{array}{c}\text { Number of } \\
\text { patients }\end{array}$ & $\begin{array}{c}\text { PRETEXT } \\
\text { STAGING }\end{array}$ \\
\hline 5,6 & 2 & II \\
\hline $5,6,7$ & 3 & II \\
\hline $5,6,7,8$ & 2 & II \\
\hline 7,8 & 2 & II \\
\hline $2,3,4 \mathrm{a}$ & 1 & II \\
\hline
\end{tabular}

Size of Lesion: (Maximum Diameter)
1. $<5 \mathbf{~ c m ~ : ~} 1$
2. $5-7 \mathbf{c m}: 6$
3. $8-9 \mathrm{~cm} \mathrm{:} 3$

Table 4: Findings on imaging in Hepatoblastoma

\begin{tabular}{|l|c|}
\hline Findings on imaging & Number of patients \\
\hline Hepatic Vein infiltration & 4 \\
\hline Portal vein infilitration & 0 \\
\hline Hilar lymph node metastasis & 2 \\
\hline Para aortic lymph node metastasis & 0 \\
\hline Diaphragm infiltration & 2 \\
\hline CXR suspicion of metastasis & 0 \\
\hline
\end{tabular}

FNAC done in 6 patients and was diagnostic of Hepatoblastoma in 4 cases. Core needle biopsy was done in 6 patients and was diagnostic in 5 cases. The number of patients who underwent neo adjuvant chemotherapy were 6 .

\section{Pretext (Pre Treatment Extent of Disease) Staging}
1. STAGE I : 0
2. STAGE II : 10
3. STAGE III : 0
4. STAGE IV : 0

\section{Indication for Neoadjuvant Chemotherapy}

1. Large size of tumor $(>5 \mathrm{~cm}$ )

2. Multiple segments involved

3. Hepatic venous infiltration

4. Diaphragmatic infiltration

The chemotherapeutic regimen used was with Cisplatin, Adriamycin and the standard number of cycles was 3, with no major complications related to chemotherapy.

\section{Re-Evaluation after Chemotherapy}

Table 5: Re-evaluation of tumor size after Chemotherapy

\begin{tabular}{|l|l|}
\hline Pre chemotherapy & Post chemotherapy \\
\hline $9 \times 8 \mathrm{~cm}$ & $7 \times 5 \mathrm{~cm}$ \\
\hline $8 \times 6 \mathrm{~cm}$ & $5 \times 5 \mathrm{~cm}$ \\
\hline $8 \times 7 \mathrm{~cm}$ & $6 \times 4 \mathrm{~cm}$ \\
\hline $7 \times 5 \mathrm{~cm}$ & $4 \times 3 \mathrm{~cm}$ \\
\hline $7 \times 4 \mathrm{~cm}$ & $5 \times 4 \mathrm{~cm}$ \\
\hline $6 \times 5 \mathrm{~cm}$ & $3 \times 3 \mathrm{~cm}$ \\
\hline
\end{tabular}


Table 6: Re-evaluation of Serum alfa feto protein after chemotherapy

\begin{tabular}{|l|c|}
\hline Pre chemotherapy & Post chemotherapy \\
\hline 22,100 & 12,000 \\
\hline 21,800 & 8000 \\
\hline 16,850 & 4000 \\
\hline 16,700 & 4400 \\
\hline 13,400 & 1100 \\
\hline 11,900 & 2020 \\
\hline
\end{tabular}

\section{Surgery}

1. Primary surgery : 4

2. After chemotherapy : 6

Table 7 : Type of hepatic resection

\begin{tabular}{|l|c|}
\hline Type of liver resection & Number of patients \\
\hline Right Hepatectomy & 7 \\
\hline Extended Right Hepatectomy & 1 \\
\hline $\begin{array}{l}\text { Non anatomic resection of } \\
\text { segment }\end{array}$ & 1 \\
\hline Left hepatectomy & 1 \\
\hline
\end{tabular}

The mean duration of surgery was $4-6$ hours. The average amount of blood loss was $250 \mathrm{ml}-750 \mathrm{ml}$. The number of intra operative blood transfusions varied from $1-3$ units.

\section{Intra Operative Complications}

1. Hypotension : 7

2. Significant bleeding : 4

3. Peri-operative rupture $: 2$

\section{Post Operative Complications}

1. Hypotension : 5

2. Hypoglycemia : 2

3. Hypovolemic shock: 2

4. Post operative Ascites : 4

5. Right lower lobe Atelectasis : 2
Histopathological examination report

1. Mixed Epithelial : 5

2. Epthelial type :

$\begin{array}{ll}\text { Fetal } & : 3 \\ \text { Embryonal } & : 2\end{array}$

Pre operative chemotherapy could have altered the final histology. Margins were clear in 9 and positive in 1 case. There were positive Lymph node metastasis in 2 cases.

\section{COG (Children's Onclogy Group) Staging}

1. Stage I (Complete resection, clear margin, pure fetal histology) : 3

2. Stage IU (Complete resection, clear margin, unfavorable histology) : 5

3. Stage II (Gross total resection with microscopic residual tumor/perioperative rupture) : 2

4. Stage III \& IV : nil

\section{Post Operative Chemotherapy}

1. Regimen : Cisplatin, Adriamycin

2. Number of cycles : 4

Complications included mortality in one case due to febrile neutropenia and sepsis. Available follow up was 3 months - 19 months. On Postoperative follow up, S AFP was less than $1000 \mathrm{ng} / \mathrm{ml}$ in all patients except 3 and USS Abdomen in 2 of these patients had evidence of recurrence, 4 -6 months after completion of chemotherapy. Maximum recurrence free survival on follow up was 16 months.

There was one post operative mortality due to persistent hypotension and unresponsive circulatory failure. 


\section{JMSCR Vol||06||Issue |08||Page 952-956||August}

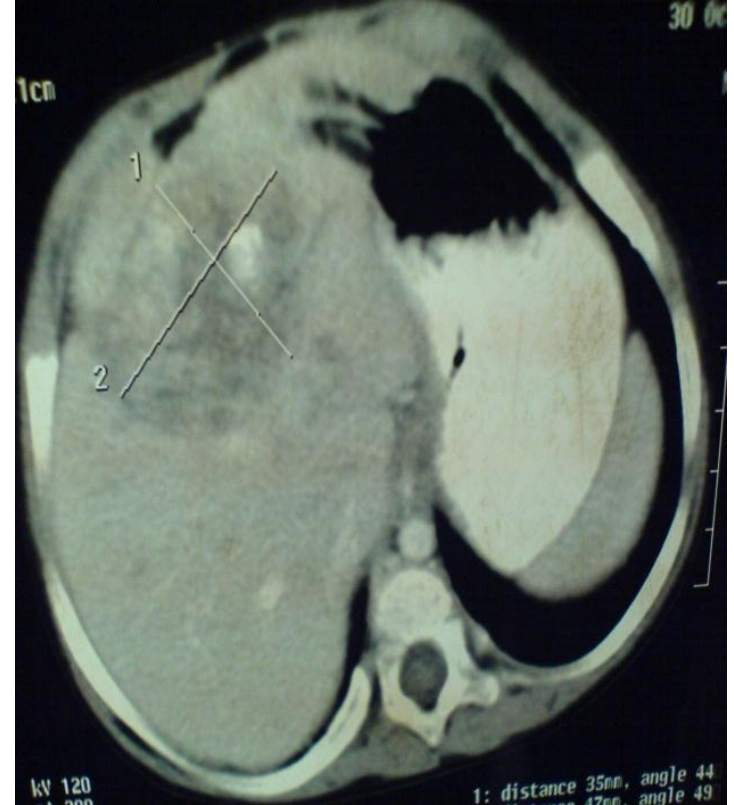

Figure 1: CT image showing Hepatoblastoma of the Right lobe

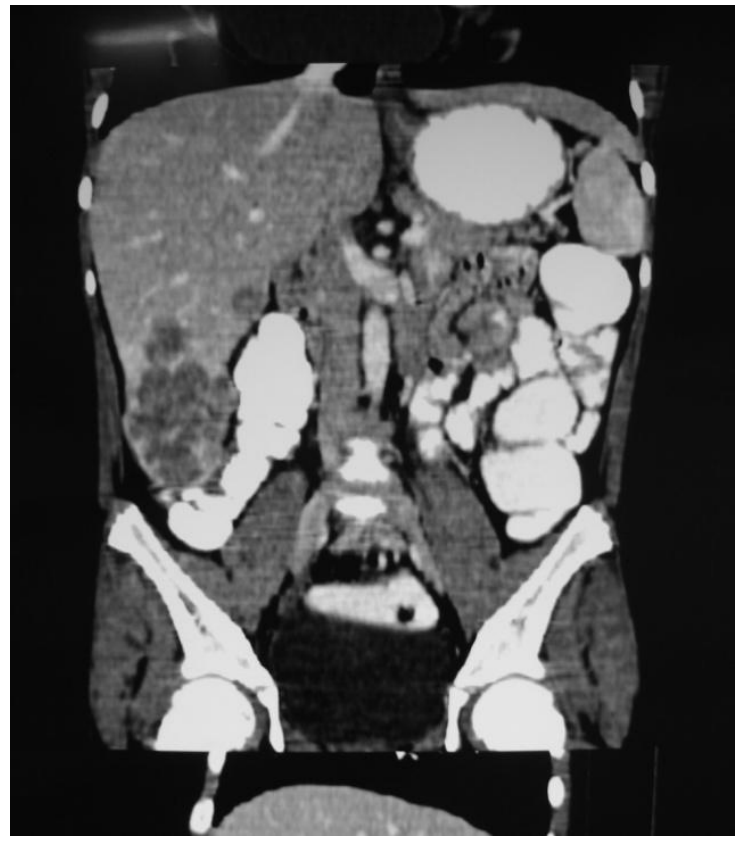

Figure 2: CT image showing Hepatoblastoma right lobe of liver

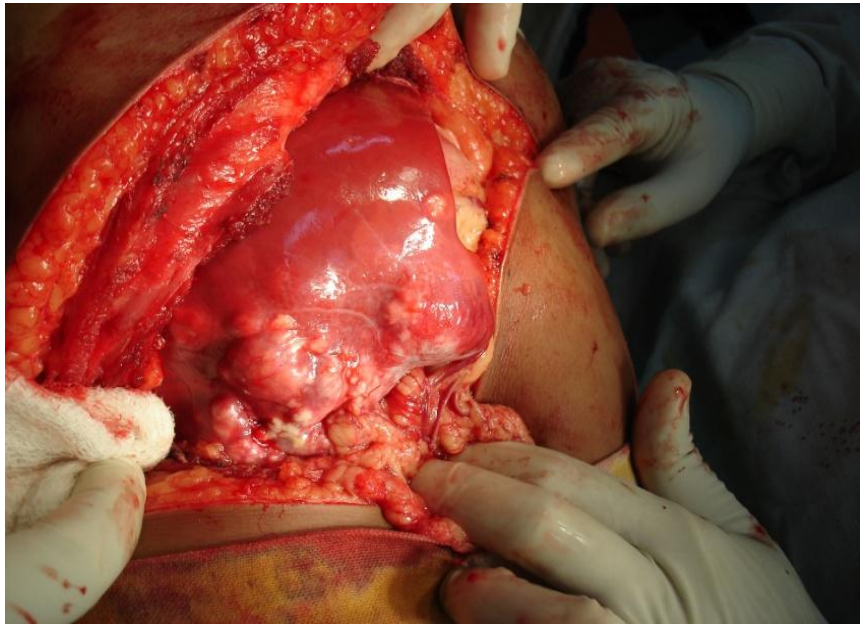

Figure 3: Intraoperative photograph of Hepatoblastoma

\section{Conclusions}

There was significant reduction in S. AFP and tumor size with the pre operative regimen of Cisplatin and Adriamycin. There was no significant morbidity from pre operative chemotherapy. Neo adjuvant chemotherapy improves the resectability in tumors without significant adverse events, signifying the importance of multimodality therapy.

\section{References}

1. von Schweinitz D, Hecker H, Harms D et al. Complete resection before development of drug resistance is essential for survival from advanced hepatoblastoma-A report from the German Cooperative Pediatric Liver Tumor Study HB-89. J Pediatr Surg 1995;30:845-852.

2. Brown J, Perilongo G, Shafford E et al. Pretreatment prognostic factors for children with hepatoblastoma-results from the International Society of Paediatric Oncology (SIOP) Study SIOPEL 1. Eur J Cancer 2000;36:1418-1425.

3. Jabra AA, Fishman EK, Taylor G. Hepatic masses in infants and children: CT evaluation. Am J Roentgenol 1992;158:143149. 
4. Pierro A, Langevin AM, Filler RM et al. Preoperative chemotherapy in "unresectable" hepatoblastoma. J Pediatr Surg 1989;24:24-28

5. Gazelle GS, Haaga JR. Hepatic neoplasms: surgically relevant segmental anatomy and imaging techniques. Am J Roentgenol 1992;158:1015-1018

6. Stringer MD, Hennayake S, Howard ER et al. Improved outcome for children with hepatoblastoma. Br J Surg 1995;82:386-391.

7. Exelby PR, Filler RM, Grosfeld JL. Liver tumors in children in the particular reference to hepatoblastoma and hepatocellular carcinoma: American Academy of Pediatrics Surgical Section Survey-1974. J Pediatr Surg 1975;10:329-337.

8. Lee CL, Ko KC. Survival and distribution pattern of childhood liver cancer in Taiwan. Eur J Cancer 1998;34:2064-2067.

9. Saxena R, Leake JL, Shafford EA et al. Chemotherapy effects on hepatoblastoma. A histological study. Am J Surg Pathol 1993; 17:1266-1271.

10. Stocker JT. An approach to handling pediatric liver tumors. Am J Clin Pathol 1998;109:S67-S72.

11. Seo $T$, Ando $H$, Watanabe $\mathrm{Y}$ et al. Treatment of hepatoblastoma: less extensive hepatectomy after effective preoperative chemotherapy with cisplatin and Adriamycin. Surgery 1998;123:407-414.

12. Bleacher JC, Newman KD. Hepatoblastoma. In: Andrassy RJ, ed. Pediatric Surgical Oncology. Philadelphia: W. B. Saunders, 1997:213-220. 